The Correlation of Mental and Physical Force; or, Man a Part of Nature. By Henry MaUdstey, M.D. LoND., Medical Superintendent of the Manchester Royal Lunatic Hospital.

1 " Han and his Dwelling Place." London: J. W. Parker \& Sons, West Strand.

2 "Essay on the Unity of Science," by Rev. B. Powell, F.R.S., \&c. 3 "Order of Nature," by the Rev. B. Powell.

4 Grove, on "The Correlation of the Physical Forces."

5 On "The Mutual Relations of the Vital and Physical Forces." Dr. Carpenter, Philosoph. Transac., 1850.

6 Oersted's "Soul in Nature."

Philosophy arrives at strange conclusions. At one time it informs man that the world in which he lives, and moves, and has his being, has no real existence ; and then again placidly assures him that he cannot be at all certain of his own existence ; consciousness it now exalts into the infallible test of truth, and then pronounces it to be the most deceitful liar; morality is eternal and immutable, and in a short time a mere matter of expediency, or non-existent altogether. Bewildered by the multitude of its variations, and by its mystical uncertainties, man at last comes to the conclusion, that philosophy itself is all a delusion, and aspires to leave its vagaries unnoticed.* But in vain; it will not be unnoticed; again, and again it raises aloud its voice and insists on being heard, reproachfully and pitifully too. "Wretched, mistaken man that thou art, how long, how long will thou rest satisfied to concern thyself with the heresy of phenomena, when there is actual existence, essence in the universe ?" Should the reply be made, that ages on ages have been passed in the attempt to grasp the essence, and yet utterly without profit, while a few years spent in the humble method of observing phenomena, have resulted in much knowledge and much benefit to humanity, philosophy, unabashed, still has its answer. Since science cannot possibly be rejected, it must be accepted ; it must be regarded as affording data on which to found the investigation into the real, spiritual, or by whatever other name it is called, and must be incorporated as an humble element into philosophy's glorious system. And thus science, which owes its own existence to the avoidance of all such speculation, is dragged in to make a pavement for this struggling, aspiring,

- In compliance with general usage, Philosophy is used to refer to Metaphysics, although, strictly, it should include all the sciences. 
ever-restless philosophy. Should science be claimed with success, we may readily conceive from the experience of the past, how much its own progress would be hampered, indeed, how soon there would be a stop put altogether to progress. What interpretation then has philosophy to offer at the present time of the universe, and what place has science in that interpretation? Why the fact is, as we are informed by the eloquent author of "Man and His Dwelling place," that after all, man is really dead, and that nature only is alive.

"Instead of dead matter the deadness is in ourselves, and we transfer our own defect into the universe wherein we exist. There is in the universe but one essence, that of spirit, which is life ; material things are phenomena thereof, appearing to us dead and inert, by reason of our own inertness. The belief in matter is in the strictest sense a superstition. It is the superstition rather; the idol or show in which we worship, in which we believe."

This is repeated so often and in such identical language, chapter after chapter, although very eloquently, and with many beautiful thoughts, that it becomes somewhat wearisome, almost, indeed painful. For there is not satisfaction to the soul's anxious longing in the dogmatic assertion, that "inertness is deadness" and in the demand "how can inertness belong to being?" followed immediately by the assertion that "here in ourselves is the being to which inertness belongs, we know it too well." We retort the question, "how can inertness belong to being?" and begin to suspect that we are tantalized with a mere juggle of words. And yet it is a philosophy which claims to be founded on science and on religion. Which if it be, it rests, verily, on foundations that are inexpugnable. Science has shown that our senses may be deceived, that the earth moves round the sun, although man long entertained the conviction that the sun moved round the earth; and, it is asked, why may not the senses be deceived when they teach man that nature is dead, and that he is himself alive. This is the whole of the argument from science, and it somehow suggests by way of commentary such questions as "why may not the sun be dark?" "why may not the heavens be only a few miles off?" and so on. Surely, too, if man be dead, animals are dead also. In fact, half nature is dead, and no man can say where death ends, and where life begins. The error which lies at the bottom of such an hypothesis, as it does at the bottom of all so-called philosophy, is that which considers man as something apart from nature, and not as a link in the mighty chain. The tendency of 
science is more and more daily to show that man is but a part of nature, and not a small god for whom all has been created, but of this more hereafter. Meanwhile, let us glance for a moment at the support which this startling hypothesis is supposed to obtain from religion; for it is in this aspect that we seem to discover its birth and growth.

"The writers of the New Testament declare man to be dead. . . . If, therefore, our thoughts were truly conformed to the New Testament, how could it seem strange that this state of man should be found a state of death ; how should its very words, affirmed by science, excite our surprize."

Granting to the author that signification which he desires to attribute to the sacred writings; granting, indeed, all that he has argued for, what have we gained thereby? Is there any gain in actual knowledge in being informed that the world is spiritual, and in being confounded by the information that we are dead? The whole argument is merely a disquisition on words, and on words that have to us no intelligible meaning. What is death, if nature is alive, and we are dead; what is spiritual, if nature is spiritual, and we are inert? We are merely changing the names of that which we know nothing about, and of which we can know nothing ; of what, by the very nature of our being, is beyond our comprehension. Does science really affirm that man is dead! If so, it is no longer science, it is nothing better than metaphysical vanity, the dead man's knowledge. No, there is no knowledge in such an hypothesis; it is nothing else but a mysticism which has its origin in the adoption of the letter of certain passages of Scripture, and the desire to reconcile these with our moral instincts. It is an attempt " to amalgancate by a transcendental solvent, ideas which belong to different schools of thought."

Few will dissent from the eloquent author, when he says that "science is religious; all things are so; nothing is irreligious, but by error and ignorance," but few will be able to congratulate him, on the result of his labours to "mingle science and religion." It is in truth a difficult task this "the great problem of the age, to reconcile faith with knowledge, philosophy with religion." * And it would not be without interest to note the changes which have been gradually produced in the relative position of religion and science, to observe how religion at one time claimed to be science, and all in all, and how, as science began to appear, it railed at and persecuted it, in time patronised it, and has at last acknowledged it. And yet - "Life of Sterling "-Archdeacon Hare. 
not universally ; for, impossible as it seems, there are yet found men to deny the plainest truths of science, influenced by a mistaken notion about religion, and others, some even illustrious in science, who torture most cruelly these truths, in order to adapt them to their religious prejudice. A late writer in the "British and Foreign Quarterly," for instance, while admitting the existence of a direct contradiction between geology and Scripture, throws the blame thereof upon the geologists.

In the last work of the illustrious Hugh Miller, there is a strenuous attempt made to revive the Biblical geology.

But, perhaps, the strangest specimen of human ingenuity is exhibited in the attempt of a celebrated naturalist, to reconcile geological revelations with the Scriptural account.* The organic fossils are merely resemblances of real forms. The first of existing plants and animals were created suddenly out of nothing, and, therefore full-grown; trees with their concentric rings, \&c. In like manner the crust of the earth was created with the fallacious marks of successive deposits. And thus, the world was really created in six days. It is not, however, of such men as Hugh Miller and Mr. Gosse that one dares to complain. Their opinions, whether right or wrong, are formed after mature deliberation, and with a full knowledge of the subject. It is the noisy and obtrusive man that is so abhorrent, who, without a particle of that moderation which a little knowledge would impart, with the selfconfidence of ignorance, throws the whole energy of passion and prejudice into a quarrel about the interpretation of a Scriptural word or sentence. Thereby he succeeds in placing science in apparent antagonism to religion, in frightening many timid people, and in placing himself in the proud position of asserting that the uncertain dictum of his judgment is more sure than the actual immutable fact of nature. This is the man who clogs the wheels of science, and acts as a dead weight on true religion. Infallible! It is not the "everlasting hills" that are facts; it is not the wondrous orbits of the planets that are certain; but, it is his individual interpretation of a sentence which was the human expression of a fact, incomprehensible by the then human judgment this only is certain. Happily, religion stands not in need of such individual's declamatory harangue, or it might go hard with it. And to us, there may be some

* "Omphalos," by P. H. Gosse, F.R.S., 1857.

See "Order of Nature," by Rev. B. Powell, where some exccllent obeervati ons are made on this subject. 
amusement, and need not be any indignation in watching the fly on the chariot wheel raise such a dust. That which has its sure and certain evidence in the heavens, in the earth, in the sea, and in all that therein is, which is fundamental in man, and in the universe, needs, forsooth, the benefit of the self-inspired enthusiast to defend it against the progress-of what ? - of truth; to defend it, in fact, against that in which it has its own sure foundations. For what is science but truth; and the knowledge we get thereby, but a knowledge of the laws of nature, which are the ways of Providence-a worldrevelation? The very object and aim of science, considered for a moment, should lead us to doubt our opinion on any subject on which we find ourselves opposed to its revelations. "It is, indeed, obvious that the works of God can never be really opposed to the word of God, and that (as it has been ingeniously and reverently expressed) whenever there is an apparent discrepancy, it must necessarily arise from an erroneous interpretation of the latter."*

And yet, so far from being general at the present day is such a conviction, that there is need of another Bacon to teach us a method of confirming a physical truth when it has already been inductively established. For, when certain things are affirmed on data, which it is impossible to contradict, and when every argument against them has fallen pointless, it too often happens that the religious danger signal is raised, and religion is brought to the rescue. And what, in reality, is it brought to support? In sooth, nothing better than man's little pride, his vanity, his idea of his supremacy, and special privileges, his refusal to acknowledge himself as a part of nature. Geology was abused, and its truths denied, because it proved that creation was a great deal more than the mere making of man; a plurality of worlds was denied, and Giordano Bruno burned, because such a doctrine was considered derogatory to man's privileges and moral supremacy; the theory of progressive development has been execrated, mainly, because it hurts man's complacent dignity ; and Galileo was persecuted, and the sun was made to move, because man had said so. Happily there is a comfort to those who mourn; time dissipates all errors, and erroneous opinions and prejudices must sooner or later give way, shattered by contact with the veracities of nature. The course of science is, indeed, as the course of nature. Proceeding according to fixed and unchanging laws, nature ignores all apparent impediments, and mercilessly crushes

- Dr. Wigan, on "The Duality of the Mind." 
whatever is not conformed to their operation. There is no respect for the ingenious contrivance of man, by which he fondly believes that' he has conquered nature; no respect for the manifold virtues by which he vainly hopes to secure a special dispensation; no respect even for that life which he so, highly values. This lordly despot who looks upon the universe as created for his enjoyment and profit, sees again and again with what supreme indifference the course of nature treads out, so to say, his highly prized existence, and is forced to confess that there is no distinction made between him and the rest of creation. And yet he learns no humility therefrom. The lightning which blasts the oak, spares not the man under it; the ocean in its anger does not become calm around the vessel, because a man cries or prays therein; and the earthquake shakes his buildings about his head, as though ignorant that a thousand human beings perished in the ruins. Man builds his houses again, forgets his wailing supplication, and again struts forth the "lord of creation." Oh ! how great is the vanity of man, "this miserable atom, this small piece of the universe." Such is man in his relation to nature, something similar are his opinions in reference to science. For the progress of science is the progress of our knowledge of nature, as crushing and as unrelenting in its course, as nature herself. Mercilessly does it upset the prejudices and grind down the idols of ages, careless of the groans and curses of humanity, in despair at the destruction of its Dagons. And yet on the ruins of old, new and obstinate prejudices spring up, sure of eternal veracity and durability, as prejudices generally are, doomed sooner or later to an unhappy fate. There can indeed be no finality in opinion, as long as there is no finality in knowledge. And man has yet much to learn, and is progressing slowly and steadily, as the Laureate says,

"For I doubt not through the ages one increasing purpose runs, And the thoughts of men are widened by the process of the suns."

Those, therefore, who would bring religion into the field to oppose the revelation of science, and those who strive to no less than dislocate the human mind, in order to make the explanations of science and their supposed interpretations of Scripture phraseology coincide, take an exceeding unhappy course, and may look out for an exceeding unhappy result. If the Scriptures are so plain "that a way-faring man though a fool cannot err therein," it is very evident that the infinite wisdom which dictated them, never intended that they should 
speak science.* For science has required ages to elaborate it ; religion was in the beginning, is now, and ever shall be the same. The Bible, therefore, does not teach science; it speaks all important truths, to man in a way he can best understand ; it is the Infinite speaking to the finite, and adapting himself thereto. Man does not rest in the same position as to knowledge; and a Bible, which spoke to him in the language of his day, would require constant renovation. Most absurd, therefore, and, most to be deplored of all, seems to us the egregious vanity of the man, who comes forward with his last discovery, or with his bundle of scientific discoveries, and parades them as destructive of the truth and authority of Scripture. He is supposing that he has arrived at finality, and yet his successor of a century hence would have a similar complaint to make against a Bible which spoke in the scientific language of to-day. Constant change is essential to the existence of man's organism; a general cessation in the activity which exists throughout is death : so it is with humanity on the whole; if knowledge does not progress, there is spiritual death. "To cease to change, is to lose place in the great race, and to pass away from off the earth with the same convictions which we found when we entered it, is to have missed the best object for which we seem now to exist." $\dagger$ And how then dares man constantly changing, constantly acquiring, as the condition of his intellectual existence, complain that what speaks to him of the never changing, should not coincide in its language with the variations of which he is the subject. When man has arrived at the Infinite, then will it be the time to complain that the Infinite is not intelligible to him. It is very much to be regretted that so eminent a philosopher as Auguste Comte, should be one of those who have endeavoured to place science and religion in antagonism to one another. After ridiculing the idea that the famous verse; "The Heavens declare the glory of God, and the firmament showeth his handywork," still preserved its value, he says, "To minds early familiarized with true philosophical astronomy, the heavens declare no other glory than that of Hipparchus, of Kepler, of Newton, and of all those who have aided in establishing their laws. I have shown that all real science is in necessary and radical opposition to all theology," \&c.+ After which he goes on to say, that "an

\footnotetext{
* "Scriptura sacra est a prophetis et apostolis ad docendum non philosophiam (quam ad exercitionem rationis naturalis contemplationibus disputationibusque hominum reliquit Deus) sed pietatem et salutis eternæ viam." Hobbe's "Le. viathan," c. viii.

+ "History of England." J.A. Froude, M.A., 1856

† "Comte's Philosophy of Science," by G. H. Lewes, Bohn.
} 
of Mental and Physical Force.

accurate explanation of our solar system shows, in the most sensible manner, and in various respects that, "the elements of this system are certainly not disposed in the most advantageous manner, and that science permits us easily to conceive a happier arrangement." The old assumption already reprobated, that " $\operatorname{man}$ is the measure of the universe." We may, by way of commentary, add the words of Lafontaine,

"C'est dommage Garo que tu n'es point entré

Aux conseils de celui qui prêche ton curé Tout aurait été mieux."

The intellectual pride of science is too apt to lead to such dangerous paths, and $M$. Comte is not the only beacon to warn us. The argument in Sir D. Brewster's reply to the celebrated "Essay on the Plurality of Worlds," is a marvellous exhibition of the vanity of intellect. The planets are inhabited, because, if not, we cannot assign the cause of their existence; we cannot conceive what else they are for, but to sustain animal and intellectual life. In fact, (for such reasoning amounts to nothing less,) in place of God having made man in his own image, man makes God at all times after his own image. It is full time indeed that man should learn to labour and to wait, content to know that he is but a part of nature, and that the part cannot comprehend the whole. "Let science follow her own path unrestrained, let her cultivate her own region-that of universal law-untrammelled by speculations, either of one kind or another, and moral reflection will be sure in the end to vindicate for itself the truths of theology, and that upon the firm and immoveable grounds, from which a true and all-influencing theology can alone take its start." " It is very difficult, however, with the best intentions, to follow such a course, so startling at times appear the revelations of science to those prejudices which are so often interpreted as religion. The "Essay on the Unity of Sciences," though of a highly philosophical type, yet affords an example of this difficulty. In it is pointed out with admirable force, that all real science is in a state of perpetual change, but that the change is all in one direction; "that every branch approaches perfection and stability, as it approaches to and realizes the grand principle of unity." The sciences of life and organization, which by some are supposed to involve a new class and order of ideas, and to stand out as exceptional cases to the general unity, are really no exceptions at all. "All myths about imponderable matters, and especially vital forces," says Humboldt, "only

$$
\text { " "British and Foreign Review," April, 1856. J. D. Morell. }
$$


render views of nature perplexed and indistinct." To attribute the causes of life and organization to something essentially mysterious and inscrutable is to paralyze research. "Everything," says the Rev. B. Powell, "is mysterious 'till it is made known, and there really exists as complete and continuous a relation and connexion of some kind between the manifestations of life, and the simplest mechanical and chemical laws evinced in the varied actions of the body in which it resides, as there is between the action of any machine and the laws of motion and equilibrium, the weaving of a cloth by a power-loom, and the principle of latent heat; and that the connexion and dependence is but one component portion of the vast chain of physical causation, whose essential strength lies in its universal continuity, which extends without interruption, through the entire world of order, and in which a real disruption of one link would be the disruption of the whole" (p. 67).

But here we come upon dangerous ground. Is man to be included in the series of nature? "Considered in his animal nature," says Rev. B. Powell, "he is very little superior to the brutes, and in 80 far as his animal nature, functions, and instincts are concerned, they are linked in the same chain of continuity with the order of other material existences."

Then, as to mind and volition, between the manifestations of which in man and in the lower animals it is impossible to draw the line: "In so far as they belong to the animal part of man's constitution, the question as to the nature of such manifestations of intelligence may be a question of degree, and may be philosophically treated as connected with other questions of man's physical development, as part of the great scale of natural existence governed by natural laws as yet very imperfectly known, but fairly subjects of intellectual enquiry."

This is not very satisfactory in an essay eloquent on the unity of sciences, and the mighty chain of continuity which extends throughout nature. In 80 far as-the continuity of our chain is interrupted, and a new order of phenomena introduced by an in so far as, without any power on our part of deciding how far that may bo. One feels moved to say after Falstaff, "I had as lief they would put ratsbane in my mouth as offer to stop it with an in 80 far as." For the difficulty is to fix the point in the manifestations of mind and volition, at which the difference in degree may be supposed to become one in kind, nature not having marked it at all clearly. It seems as though at this 
point in the essay some small voice had whispered to the learned author: Put off thy scientific shoes from off thy feet, for the place whereon thou standest is holy ground. And the advice is accepted; in a moment more there is a bound quite out of scientific trammels, and man's moral and spiritual nature is referred to a wholly "different order of things, apart from, and transcending any material ideas whatsoever. Hence, it cannot be affected by any considerations or conclusions belonging to the laves of matter or nature." We are at once carried out of the domain of science; the ground is, as it were, suddenly taken from under our feet, and we are left, it must be confessed, with no clear idea of where we are. Two impressions gradually become distinct to our minds. The first is, that it is very unlikely that there should be two such essentially distinct orders of phenomena in the universe; that, in fact, it is almost inconceivable that there should be a unity and continuity throughout the mighty field of nature, that continuity extending far into man's own nature, there suddenly to be broken off. Mr. Baden Powell himself considers, that mind in that department of its operations which are independent of physical laws, is yet "governed by equally regular laws of its own." We are required, therefore, to believe in two separate and distinct systems of laws in the world, we are required to believe in a mind, which "in so far as it is physical," is subject to one system, and "in so far as it is metaphysical," is subject to the other,yet systems unconnected and independent. Whether such a doctrine is accepted or not, will probably depend on the character of the individual mind. Secondly, we have an impression, almost amounting to conviction, that to assert that moral phenomena are not affected by any condition of matter, is very far from being a correct statement. + Without claiming, as $\mathbf{M}$. Comte does, the scientific cognizance of moral and intellectual phenomena exclusively for the physiologists, and placing mental philosophy on a par with astrology, many eminent men entertain the conviction that "every mental state has a nervous state for its immediate antecedent and

* "Unity of Science," p. 215.

† Spinoza in his Ethics says, "Qnæ omnia satis ostendunt, unumquemque pro dispositione cerebri de rebus judicasse, vel potius imaginationis affectiones pro rebus accepisse. Quare non mirum est (ut hoc etiam obiter notemus) quod inter homines tot, quot experimur, controversim ortes sunt, ox quibus tandem Scepticismus. Nam quamvis humana corpors in multis conveniunt in plurimis tamen discrepant, et ideo id quod uni bonum alteri malum videtur; guod uni ordinatum, alteri confusum, quod uni gratum, alteri ingratum est." -Quoted in Lewres" "Life of Goethe." 
proximate cause ;" indeed, this is all but proved. But without entering into an unnecessary discussion on this point, or upon the order of things to which moral phenomena belong, it remains a fact, that from considerations of matter only, one can predict, to some extent, moral nature; and to such an extent, that we are justified in the belief, that were our knowledge of matter greater, this power of prediction would be increased also. Phrenology is, doubtless, often at fault in its details, but it is founded on a fact, which is almost as certain as any principle of science, that the character and confirmation of the brain, and the nervous susceptibility, determine in this world the moral and intellectual nature of the individual. Of course this nature is modified by circumstances, but these modify the brain also; in fact, it is a law of the nervous system to "grow to circumstances." But every-day experience, as well as pathological observation, will supply hundreds of examples of the direct manner in which moral character is influenced by the physical state. "I firmly believe," says Dr. Wigan, "that I have more than once changed the moral character of a boy, by leeches to the inside of the nose."*

It would be gratifying to learn what signification the assertion of a distinct moral nature bears to human knowledge. If there was anything gained by a belief therein, one would be only too glad to accept it. Even if the supposition of a moral sense, or intuitive moral principle could be shown to be a necessary and satisfactory principle, there would be much hope from it, and immediate acceptance of it. But even if the doctrine were true, "it would provide only for that field of conduct which is properly called moral. For the remainder of the practice of life, some general principle or standard must still be sought; and if that principle be rightly chosen, it will be found, I apprehend, to serve quite as well for the ultimate principle of morality, as for that of prudence, policy, or taste." $\dagger$ If human nature could but be divided and mapped out, and human principles of action discriminated and specialized as certain human ideas require, what a host of difficulties would be annihilated. But it is just the fact, that everything in man is part of a whole, and that whole but a part of the greater whole of nature, which prevents doctrines so pleasing to human vanity from affording definite and satisfactory explanations of facts. "The connected series of physical causation is the manifestation of moral causation," as Baden Powell himself says; and it seems impossible to believe that the

* "Duality of the mind."-Dr. Wigan, p. 16.

† "System of Logic."-J. Stuart Mill, vol. ii., p. 529. 
moral man stands distinct and apart from a morally governed universe. Placing side by side the title of the essay, "On the Unity of Sciences," and that of the last book of Mills' Work on Logic, "On the Logic of the Moral Sciences," there is a pleasure in believing that the tendency of the age is to extend the unity spoken of in the former throughout the whole of the latter.

Should it be said in reply to the assertion, that moral nature is determined by cerebral state, that it is merely the operation of the moral principle which is influenced, whilst its nature remains always the same, such a reply may be extended to mind in all its manifestations; to "mind and volition" in their lower functions, in 80 far as they belong to the animal part of man's constitution. If the unity of science extends into these, and they are fit subjects for scientific cognizance, there seems no reason why the character, operations, and relations of the moral principle should be exempt. But, in reality, such a doctrine, which we find so frequently enunciated in the case of mind and brain, is a self-deceiving sophistry. If the manifestations of mind are only through the medium of a certain organization, it is the manifestations only that we have to do with in this world ; these constitute the character, these are the individual. The mind in its own immortal nature may be "unchanged and immutable by anything of earth " but it is then no longer individual mind, it must be evidently the same in every one; individual character is annihilated beyond the body, and there is no distinction of persons. The brain in fact is, as one cannot but think the most philosophical of the Apostles clearly saw, essential to the existence of the mind as individual ; if we believe otherwise, we must believe in the veriest Pantheism that ever was dreamed. It is difficult to understand why there should be any objections, on religious grounds, to language which speaks of mind being dependent on brain, being in fact a function thereof, when our religion teaches that Christ raised Lazarus, and rose himself bodily from the grave, when St. Paul distinctly preaches the resurrection of the body, and when Job confidently affirms, "in my flesh shall I see God." Nevertheless, man blinded by his vanity, and by the mists of metaphysics, ashamed apparently of his body, as having so much in common with the rest of nature, cannot bring himself to acknowledge it, and with many an opprobrious name brands those who teach so humiliating a doctrine. The irreligion, if any there be, is on the side of those who will insist on ignoring the organism, and viewing man as mind; 
mind chained, as it were, for a time, but scarcely acknowledged to be determined in action, even by its chains. Irreligion is not with those who, following scripture, and learning humility, reverently refrain from assimilating themselves to the Infinite, and humbly hope "in the flesh to see God." Surely then science is justified by scripture in viewing man as a material being, and as a part of the vast structure of the universe, which for some wise end Infinite Wisdom is governing in such wondrous harmony and order. Considering the history of the universe, as it is disclosed to us, and the nature of man as it is forced upon us, and reflecting on the aspect which science gives us of nature, it seems impossible to believe that man is the end of creation. And yet such is his exceeding great vanity, that a doubt on the subject rarely presents itself; and it yet remains for him to learn that he is but a link, and that not the last link in the mighty scheme of the universe. $\mathrm{He}$ is a part of nature, and like everything in material existence, produced from "particles of matter by the same forces, and in obedience to the same laws." The laws of man's reason are laws of nature, and the laws of nature are laws of reason, as Oersted has taught," and herein is the harmony which is described by some as existing between man and nature.t Such a consideration also will incline us to expect that the multitude of speculations which the human mind has through successive ages been engaged in, have not been altogether vanity. They are, for the most part, operations of reason, often in giant minds, and must, therefore, have in them something of the truth in nature. They express, as it were, in a different language the facts which positive science now expounds in its own language; and a liberal translation, when the time has come for it, will probably show that there is in very truth " nothing new under the sun." This, however, is a subject for separate consideration, and may be advantageously discussed on a future occasion.

For the present our duty evidently is, in recognising man as a part of nature, to glance at the forces in the universe, and their relation to one another; and on this subject recent science has made most important revelations. In his important work on the "Correlation of Physical Forces," a book which will probably be one of the most notable in the history of science, Grove has pointed out how questionable it is, not only whether "cause and effect are convertible terms with antecedence and sequence," but "whether in fact, cause does 
precede effect, whether force does precede the change in matter, of which it is said to be the cause." "The common error consists in the abstraction of cause, and in supposing in each case a general secondary cause, a something which is not the first cause, but which, if we examine it carefully, must have all the attributes of a first cause, and an existence independent of, and dominant over, matter."

Electricity and magnetism furnish examples. Electricity was supposed to be the cause of magnetism, but magnetism may cause electricity ; ergo, electricity causes electricity, a reductio ad absurdum. And so with other cases, from consideration of which the author has been led to the conclusion, that "abstract secondary causation does not exist." Cause and effect, therefore, are relative terms ; there is a correlation of the forces in nature, one is convertible into another, but no one is the essential cause of the other. One form of force disappears as another is evolved, and from a single source we may have all the great natural forces of which we have any knowledge (with the exception of gravitation) evolved.*

"The same electrical current from a voltaic battery is capable in its circuit of evolving heat and light, of creating magnets, of producing mechanical force, of violently affecting the nervous and muscular organization, and of inducing by decomposition or combination the most powerful chemical changes, simply according to the nature of the different material objects which the experimenter interposes in the circuit, so as to subject them to the current of power." +

All these forces are to be considered as forms of one and the same force, varying only in its outward manifestations. There is but one condition wanting to convert this doctrine into an unimpeachable scientific truth; it is proof of a quantitative equivalence of the various forms of force. "Heat should be capable of being convertad into electricity, electricity into chemical action, chemical into mechanical force, and mechanical force back again into the very same quantity of heat which was expended at the commencement of the series."+ This demonstration will, doubtless, be acquired in time, and meanwhile there is evidence enough to justify us in accepting

\footnotetext{
* Gravitation also will, doubtless, in time be shown to be no exception. Faraday observes, "that there should be a power of gravitation existing by itself, having no relation to the other natural powers, and no respect to the lavo of conservation of force, is as little likely as that there should be a principle of levity as well as of gravity."-On the Conservation of Forces.

+ Edinburgh Reviewo, July, 1858.

¥ "System of Logic."-J. S. Mill, vol. i., p. 477.
} 
the doctrine of the Correlation of Physical Forces, and in awaiting with confidence the full proof.

But when we once admit the principle of correlation, we find a considerable amount of evidence disclosing itself in favour of a further extension of it. Man, as has been already repeatedly said, is but a part of nature, and subject to the laws which govern matter throughout the universe. To the development of his organism, heat is as essential as it is to the budding of a flower, light as necessary as it is to the proper growth of a plant, and the chemical force is as active in man's body as it is in any other product of nature. What relation then does the force which has constructed the organism, the germ force of Paget, bear to the other physical forces? Does it rank in the correlated circle? There are many minds in which analogy, without any aid from special observation and experiment, would produce the conviction that it does. The evidence of observation is not, however, wanting in favour of such a belief. Liebig had indicated the relation, but it is Dr. Carpenter who has proclaimed it distinctly, and mainly contributed to establish it. Liebig had shown how very closely chemical processes are engaged in all the great processes of animal life, and that it was highly probable that muscular contraction proceeded from the expenditure or metamorphosis of the cell-force, which ceased to exist as a vital force in giving rise to mechanical agency; while the experiments of Matteuci and Du Bois Raymond have demonstrated the intimate relations which exist between electricity and nervous and muscular action. Dr. Carpenter has given the interpretation of these facts, in placing "vital force" in the circle of correlation with the physical forces; he traces further a correlation among the several forces (assimilative, secretive, \&c.,) to whose agency vital phenomena are attributable. The term "germ-force," therefore, used by Paget, can only be understood as a " comprehensive expression of all the individual forces which are at work, and so far from residing within the germ, it is of external origin." * And, verily, as Grove has observed, "it is certainly far less difficult so to conceive the supply of force yielded to organized beings in their gradual process of growth, than to suppose a store of dormant or latent force pent up in a microscopic monad."

If such then be the position of the so-called "vital force" in its relation to the physical forces, it is no wonder that the

* Philosophical Transactions, 1850. Dr. Carpenter " on the Mutual Relations of the Vital and Physical Forces." 
organism throughout life should be so much influenced by the powers without ; it is no wonder that it should grow to circumstances in the way it does; for the forces that are affecting it are in reality the force that is in it under different modes. To any change without there will be an answer within; to any disturbance without a responilent irregularity within, which may manifest itself in a modification or a disease of the organism, in the blighting of a flower, or in the purging of a man.

But there is another doctrine regarding the so-called "vital force," which was entertained by some of the old philosophers, and which has again been put forth at the present day-of much interest and importance, when viewed in relation to the correlation of vital and physical force. It is that which regards the soul as operating unconsciously in the construction of the organism. "The soul and the body," says Morell," "are perfectly coincident; the soul is prior to consciousness; it exists unconsciously from the formation of the first cellgerm." Dr. Laycock also looks upon "the human mind as none other than the unconscious working principle of intelligence individualized, and become conscious of its workings in the cerebrum."

What at once strikes us in this doctrine as somewhat extraordinary and improbable is, that in the construction of organisms which form such an important part of nature, a force should be in operation which has no relation in its nature to any other of the known forces at work in the universe, and which is, nevertheless, notably influenced by them. It looks like filching away from science the most interesting field of its labours, by referring to a different order of things, phenomena of which science feels itself capable of taking cognizance. Those who describe organic growth and development as the results of "vital force," operating according to certain laws, can feel no scruple in admitting its probable correlation with the other natural forces, by which its agency is so much modified ; but when we substitute for rital force the unconscious intelligent soul, a difficulty will arise in the minds of many, in adnitting that correlation, which the analogy of nature renders probable. But are the two doctrines really incompatible? To suppose that they are not is startling, for it is to suppose that mind is one of the correlated forces of nature. And yet there are many weighty arguments in favour of regarding the constructive force as unconscious soul. The marked intelligence which it exhibits

voL. v1. No. 31 .

$$
\text { * " Elements of Prychology." }
$$


in all its operations in the building up of the organism, indicating a completer knowledge than is ever acquired by the conscious soul, and which, indeed, it is the constant aim of the latter to attain to; the reason with which it adapts its structure to the varying circumstances in which they are placed, apparently yielding to the powers of nature, but in reality subjugating them, so to speak, to the advancement of its end, compel admiration, and at least the acknowledgment, that there is nothing extravagant in the supposition of its nature being identical with that of conscious soul. In point of fact, its mode of action is precisely that which Bacon asserts to be the characteristic of the enlightened scientific mind-" it conquers nature by obeying her." If we contemplate its history, as written in the infinite multitude of organic structures, and their appropriate distribution, or in the infinite variety of structural changes by which both plants and animals are adapted to new external circumstances - in the intelligent action too of the new machinery, as exhibited in acquired instincts and habits-it will be impossible to deny that this unconscious soul is eminently world-conscious. Every organism is, in fact, an intelligent response to external forces. Unconscious, indeed, this intelligent power, which with such wonderful uniformity elaborates material, and with such unerring precision applies the different varieties to their different purposes, so that even the scar on the child's finger is not forgotten, but appropriately nourished, grows as the body grows, and which in the unfailing constancy of its action, often brings recollection to the forgetful, conscious soul. Doubtless, the unhappy sufferer who sees the syphilitic spots sprouting out over his body years after the original sin, would wish that it were not quite so sensitively alive to outward agencies, and at times a little more oblivious of them; but in vain. Conscious soul may forget; unconscious soul does not. It is true that all its operations are performed quietly, without other notification than the result; but if some disturbing agent interfere with its peaceful action, it is admirable to observe how speedily a consciousness thereof is exhibited, and what intelligence is manifested in the means adopted to remove the impediment. It is thus that the oyster produces its pearls, that the lobster throws off its claw, and that man recovers from gangrene. Disease itself is the evidence of the world-consciousness of this force, and the "vis preservatrix naturce," the manifestation of its intelligence. Which is the more certain index of the state of the extermalconscious or unconscious soul? Let plague, fever, cholera, 
and a host of other diseases answer. We may justly then echo Spenser's creed, that

or say with Virgil,

"Soul is form, and doth the body make;"

$$
\begin{aligned}
& \text { "Totamque infusa per artus } \\
& \text { Mens agitat molem." }
\end{aligned}
$$

The intelligent adaptation of structure to circumstances, by the so-called vital force, has already been mentioned, and needs no illustration here; but we may reflect for a moment with advantage on the perfect correspondence that exists at all times between physical structure and the "indwelling selfconscious reason." Thus consider for a moment the eye of such admirable mechanism, that each fresh contemplation of it calls forth fresh exclamations of wonder. The light is adapted to the eye, and the eye is so formed as to produce by concentration of its rays an imuge on the retina, which the mind can receive. Is not reason exhibited most notably in the construction of the eye, and is the force (mind) which owes chiefly to this very structure its power of detecting the reason in nature-in fact, mainly its own existence-is it essentially different from, and superior to, the power which has constructed the admirable organ? Or, again, considering the adaptation of light to the eye, as well as of the eye to mind, is it probable that there is a correlation between the force, whatever it be, which is light, and the force which has been engaged in the formation of the eye, and no correlation between the latter and the force which appears as mind? The more one reflects upon the subject, the less easy does it become to avoid the conviction, that the self-conscious operates unconsciously in the construction of the organism, that vital force is soul.*

To what point then have we arrived? We have seen that men in olden times, and at the present day, uninfluenced by any theory of the correlation of forces, have taught on evidence

\footnotetext{
* "Similar views respecting the essential homogenity of mind and nature were entertained by Liebnits in his Monadology; and afterwards illustrated in a series of letters published amongst his Opuscula. Modern science and philosophy, instead of refuting these speculations of, perhaps, the greatest of modern thinkers, has only availed more and more to prove their fundamental consistency, with the principles both of thought and existence. Whatever research, either on the physical or mental side, has proceeded far enough to open the question at all, it has almost uniformly shown a manifest tendency either to reear to the point where Liebnitz left it 200 years ago; or to restate the theory in a more perfeol form. Among modern writers we may mention Alex. Von Humboldt, Waitz, Carus, Oersted, Erdmann, Karl Schmidt, \&c., as having given clear illustrations of the unity of idea which reigns through the world of mind and nature." -Note in Morell's "Elements of Psychology," p. 46. 
that has not been refuted, the identity of soul, and of the forcetwhich is engaged in the construction and maintenance of the organism. We have seen, moreover, that others unbiassed by any theory with regard to the soul, which they leave out of consideration as beyond their domain, have taught, and on evidence which establishes conviction, that there is a correlation between the organic force and the physical forces. The conclusion then is inevitable ; there is a correlation between mind and physical force, between all the forces of nature. Verily, verily then is man indeed but a part of nature.

But confining attention for a moment simply to the forces in man, irrespective of any theory of correlation of forces, and leaving out of consideration the physical forces, we find that we are unable, reflect and observe as we may, to distinguish their effects. It is, in fact, impossible to discriminate between the vital and automatic acts, and the proper functions of mind. There is no certain boundary line, not even an uncertain boundary line, " no absolute gap between the unconscious and self-conscious portions of the universe." Are we then to suppose that there are in man two forces essentially distinct in nature, belonging to different orders of things, yet merging so gradually the one into the other, that the most acute philosopher is unable to say at all times which is which. Nature everywhere proclaims a gradual progression, and science has at length understood the proclamation, and has discovered that a "law of progression" does pervade the universe. And yet we cannot bring our minds to accept the law purely and simply; we must actually go out of the way to invent difficulties. Instead of accepting nature, we devise theories, and endeavour to make nature appear anomalous. Where there is a gradual progression, with no gap, no interception, we must imagine forces unrelated and essentially distinct in operation. We assume the right to make a monstrous gap between the forces, and then are actually astonished, and unable to explain that there is no gap in their operations. It is almost needless to enquire how this happens. It has its fundamental origin in that propensity already reprobated on the part of man, to ignore himself as a material being, and to speculate loosely and dilate rapturously on his mental being. He finds much inward gratification in speculating on a force which he begins by assuming to be independent of all other forces in nature, and resolves to examine it exclusively on its own merits. The scientific man does not attempt to ignore heat in his consideration of motion, or magnetism in his 
examination of electricity, and yet the man who boasts of being the "philosopher" par excellence, does in his metaphysics exclude everything but the one which he professes to be studying. Hence it is not at all astonishing, that of all vanities, metaphysics is the vanity of vanities, and that the study thereof (' art de s' égarer avec methode-the art of methodically "muddling" oneself,) is a vexation of spirit. It appears as though in the study of mind the right course would be to observe the relation of phenomena, as it is in the study of the external world. In the latter, it has been agreed to dismiss as vain the question of essences, and to confine the attention to phenomena; but in the field of mind, the hypothesis of essence still excludes the proper course of investigation, and effectually prevents progress. Yet withal there is some difficulty in understanding why we should cling so tenaciously to the erroneous method; for the physical forces, we cannot but see, operate in the most intelligent manner in the universe, and exhibit a higher reason than any to which man has ever attained; and surely there is no extravagance in supposing that the great cause which has determined the laws according to which they act so harmoniously throughout nature, may have determined a similar intelligential operation on the part of a correlated force in man. Our highest efforts in science are directed to detecting the reason that is in the universe, and thereby ourselves acquiring knowledge. Man, indeed, only progresses in knowledge in so far as he progresses in physical science; it is in this mainly that the progress of civilization has consisted. The intellect in the days of Aristotle and of Plato was probably not inferior in itself to the intellect of modern times, and its cultivation was as great in Greece as it has been in civilized England. But the method was erroneous in the days of Plato. The inductive investigation of nature of the spirit of which Bacon was the expression, and the progress of positive science, have supplied to modern mind a better nourishment, and have conferred upon it a greater power. Knowing the physical laws, man can employ the physical forces for his purposes; these are brought into subjection, and the proposition of Bacon, that "man conquers nature by obeying her," is realized. There is, as it were, a double correlation between the laws and reason of nature, and the mind's knowledge (science), and again, between the latter and the world of art. It is the world acting on man, and man reacting on the world. Buckle, in his learned work on the "History of Civilization," has argued very eloquently, that 
science only is progressive, and that morality is not; and it is so far true, that no change has taken place of late in the principles of morality; but it seems impossible to deny that there has been an extension of the application of those principles-an increase in practical morality ; and this, not as the result of any supposed exacerbation of moral principle, but as the simple and inevitable result of the progress of science. The abstract moral truth, that man "should do unto others as he would have others do unto him," though for ages preached and for ages recognized as true, could not avail to induce the rich man to improve his poor neighbour's pig-stye habitation. And the poor man being left, morality notwithstanding, to live like a pig, acted in some measure also like a pig. But modern science has taught that a filthy habitation, and a foul atmosphere, and unwholesome food, are directly destructive to human life; and cholera and fever have done what religion and morality had attempted and failed to do; and now, as the result, is appearing the dawn of a social science.

Thus, then, the advance of civilization, consisting in a progress of the intellect, is owing to the progress of man's acquaintance with the laws of nature. It is the mind responding to newly-discovered laws of reason, by virtue of the correlation of forces ; Antæus-like, it gains new life by contact with mother earth. Yet, partly by reason of the exaggerated idea which we entertain of our individual selves, and partly from our familiarity with the physical forces, we refuse to recognize such a doctrine, deeming it to involve a fearful degradation of our spiritual nature. Because, forsooth, man can bottle electricity, he fancies that it is not very wonderful ; he underrates the nature of this force, and overrates mind, at least comparatively, as though Providence had not sent one forth to do its work in the world, just as much as the otheras though God were not omnipotent. But the fundamental error which appears to lie at the bottom of man's opinion on this subject, as, indeed, on a good many others, is his inability to rise out of himself; he cannot emancipate himself from the tendency which is so general at the commencement of speculation, to regard all things with reference to himself personally. On the whole, this is, perhaps, not to be wondered at, seeing how he is materially affected, for pleasure or for pain, and is a considerable part of the whole. Yet the progress of science tends to show that what we have to learn, is to observe objects not as related to $u s$, but to one another, and not only so, but to place ourselves on equal terms amongst the objects 
whose relations we are to observe-to become, as far as possible, indifferent spectators of these relations, forgetting, as far as may be done, that we are interested and affected parties. Man is certainly too personal, and much needs to be brought back now and then to his cradle in the dust; he would do well to observe how nature everywhere proclaims his individual littleness, to listen to the "tongues in trees," to attend to the "sermons in stones," and to read the "books in the running brooks." Thus to give an illustration of what, perhaps, yet remains to be learned from the "tongues in trees," regarding the subordinate part which the individual plays in the mighty scheme of the universe, let us instance the phenomena of nutrition and reproduction. In the lowest plants and animals, generation is but nutrition directed to a particular purpose. A cell, to all appearance, breaks off indifferently somewhere from the parent, settles down and grows into a new organism; or, ascending a little higher in the scale of organization, there is a budding (gemmation) from some part of the parent, the bud increaising and remaining for some time attached, perhaps, permanently so, or at other times breaking away and becoming a new organism. Amongst physiologists, some will not consent to call this a new individual, while others do-a fact which is not without interest. The germ which is to become an oak, becomes 80 by a succession of buds developing year after year, each as its immediate work is done, remaining to constitute a part of the individual ; each bud is, so to say, a brick added to the house. In such a consideration, taken in connection with what human history teaches, is there not a useful lesson for man to learn with respect to his individual littleness in this world? His reproduction is but nutrition, under less patent, more complex, and more exalted conditions, than in the plant; and what are the successive generations of a family, but so many buds, which, if not blighted, are to culminate, at some period, in the family oak? There were many Mirabeaus, doubtless, who lived and died un-noted before the world-noted Mirabeau appeared, who performed such an important part in revolutionizing the world. In him the Mirabeau family tree attained its full growth, and the full performance of its function, and then, having done its duty, decayed. As individuals, we have fax too exalted notions of ourselves; thousands appear to exist only as bricks to build the house, or as buds to build the tree; we are steps in the evolution of a mighty scheme, for, as individuals, we are, many of us, no better than "stuffed clothes-suits." So also may it be with regard to nations, for 
it is important to bear in mind, "that centuries form but short periods in the history of the human race." And, although "it may be dangerous," as Oersted observes, "to wound the self love of the human race by the supposition that it must one day make room for a more perfect order of beings,"* so also may it be with the whole creation which "groaneth and travaileth," to some wise and glorious end. Perhaps when man has brought himself clearly to recognize these things, he may not find it so hard a matter to place himself in the circle of correlation.

Turning back, then, as physical enquirers to the contemplation of man, and adopting the physical maxim, de non apparentibus et non existentibus eadern est ratio, it seems impossible to resist the conviction, that mind must be correlated with the other forces of nature. What means else the never-ceasing dependence of mind on brain? When we reflect on the gradual development of brain throughout the animal kingdom, and on the uniform correspondence that there is between increase thereof and increase of mind, when we observe how invariably in man himself a deficient brain is associated with deficient mental power-how notably concomitant are their variations-when we find that injury or disease of the former, is injury or disease of the latter, and that the development of mental force is attended with a change or "waste," as it is called in the material substratum, we cannot but acknowledge that mind exists only to us as evolved through the material substratum of the brain. As forcibly expressing this, we may venture to quote, although it is dangerous to tread on such ground, the very eloquent words of Lawrence. $\dagger$

"Examine the mind, the grand prerogative of man. Where is the mind of the foetus ? Where that of the child just born? Do we not see it actually built up before our eyes by the action of the five external senses, and the gradually developed internal faculties? Do we not trace it advancing by a slow progress through infancy and childhood, to the perfect expansion of its faculties in the adult, annihilated for a time by a blow on the head, or the shedding of a little blood in apoplexy, decaying as the body decays in old age, and finally reduced to an amount hardly perceptible, when the body worn out by mere exercise of the organs, reaches by the simple operation of natural decay, that state of decrepitude most aptly termed second childhood?

\footnotetext{
" "Soul in Nature," p. 53. t."Lectures on Man."
} 
"Where shall we find proof of the mind's independence of the bodily structure? of that mind, which like the corporeal frame is infantile in the child, manly in the adult, sick and debilitated in disease, frenzied or melancholy in the madman, enfeebled in the decline of life, doting in decrepitude, and annihilated by death."

This looks very much like the expression of a pure materialism, and therein can be in nowise acknowledged here. It speaks of annihilation by death; there is no annihilation in nature-force cannot be annihilated. It is not, therefore, identical with the doctrine of correlation of physical and mental force-very far from it ; the latter is, indeed, identical in all but name, with the doctrine of independent mind. For when we speak of mind independently of brain, we have no idea of it, except as of a something - essence, perhaps, unmeaning word-which we suppose to exist beneath the manifestations of which we take cognizance, and which constitute individual character. There is no knowledge in such a supposition. Should we not, abjuring all speculation about the nature of mind which never can be knowledge to us, gain something by regarding it as a force of nature ? Nothing, truly, if we look upon it as a force, special, independent, and unrelated in nature; but the idea of force should be entertained, because it expresses a relation with other forces, and thus, admitting a correlation, we hope to have gained something, and may expect to gain more. Moreover we lose nothing. We have all that is required in mind, and are enabled to recognize man as, what all observation points him out to be, a part of nature. But it may be denied that such a view supplies all that is required in mind. What about consciousness? Here then we have the "cogito ergo sum" of Descartes starting up and staring us in the face, as it appears destined to do, as long as the hinges of gravitation keep the world in its orbit. It is this which boasts of annihilating the materialist, by pointing out to him that he loses "the unity of the whole man in the multiplicity of the material organs," although the materialist replies with some cogency, that the unity of mind is preserved by his adversary, only by "grasping it as a verbal abstraction." One generally finds that one doctrine hits very decidedly the weak point in another; and it may happen, that by bringing together the rival criticisms, and reconciling them through the medium of a third hypothesis, some advance is made in knowledge. We have no intention 
of entering the weary labyrinth of a metaphysical disquisition on consciousness; it seems a question never to be settled: Buckle, only a short time since, asserted, that the metayhysical dngma of the supremacy of human consciousness involves two assumptions; one, though possibly true, which has never been proved, the other unquestionably false. These are, that there is an independent faculty, called consciousness, and that its dictates are infallible. But the ablest thinkers, says he, now regard consciousness as merely a state or condition of mind; and the argument, therefore, falls to the ground. Even if it is a faculty, we have the testimony of all history to prove its extreme fallibility. Of course this is not to be admitted without energetic protest, and in the discussion thereupon, such a cloud of dust is raised, that none but those provided with metaphysical spectacles of high power are able to discern anything. For the metaphysical spectacle is wonderful in the power which it possesses, of enabling a man to see things in words. Refraining then from the futile attempt to soar upwards without wings, it will be sufficient to consider consciousness on the basis of physiology- to look upon a state of consciousness as a state of brain. If we are not to do this, what position are we to assign consciousness in a physiological psychology? There is considerable difficulty, indeed, actual impossibility, of understanding how these, who acknowledge that mind can manifest itself only through brain, dispose of consciousness, which they appear to think it incumbent on them, somehow to exempt from the supposed degradation of a material necessity. It is, of course, impossible to doubt that consciousness is the ultimate ground of certainty for the individual ; if he is conscious of pain, he must feel pain. But is there not a material change in the organism which is the condition of the excitation of the feeling, and must not consciousness so aroused necessarily certify to it? The effect must infallibly testify to its conditions. Consciousness is infallible, therefore, as to the internal fact, but it is quite a different thing to say that it is infallible as to the external phenomena, that it demonstrates the truth of them. It is the expression of a transmutation of force, and the testimony, therefore, of its own existence; but it is not necessarily an expression of the nature of the affecting force.

Again, there can be no doubt that consciousness irresistibly suggests the ego, but this does not appear to be incompatible with its material origin. Inasmuch as it is through 
an affection of $m y$ organism that it is aroused, it is difficult to understand how it could suggest anything else ; the unity of $m y$ consciousness is the unity of my organism; my ego is the ego of my body. Amidst the multiplicity of material organs and operations there is ever a unity maintained; all the parts increase and develop after a definite plan, and work together for a common object; a certain type is preserved. We may speak of it as a type, or we may speak of it as a thought of the creative mind, but that the organism is the realization of such a type or idea, can admit of no doubt. Changing as it is constantly through life, it never loses its type ; it receives experience, and makes it a part of itself ; responds to correlated force, and registers its reply. For all impressions leave in man's organization certain traces, more or less clear of their existence, which, by virtue of the laws of nutrition, are propagated, and thus modify the existing condition, always consistently, however, with the maintenance of an original type. We may justly, therefore, consider the body of a man, aged 30 , to be the body of 20, plus the incorporation of 10 sears' experience. There will, then, be in mental phenomena a modification, but not radical change of force, through the substratum of a modified, but not radically changed organism; the typical unity of the latter having been maintained, that of the former is also preserved. Endow this force with the nonessential quality of consciousness (for be it observed the mind may be actively employed without consciousness), and what is it then conscious of? It is conscious of manifold changes produced by external circumstances, which, by the laws of nutrition, have become part of the organism, but it is conscious also of the preservation of an original type, just as the on-looking physiologist is. And the consciousness of this, what is it but the consciousness of personal identity? It is the corporeal, and, therefore, mental identity, maintained in the midst of an infinite multitude of changes. Refined by intellectual exercise, scarred by passion, or blunted and dulled by sensuality, the organism preserves unchanged its type; its unity is unity derived from the same source as the unity of creation. In the assertion that the unity is in consciousness, there is not only an assumption which is not necessary, but which is not equal to the explanation of all the phenomena of mind ; the unity being in the organism, the mind as manifested through it, necessarily contains in itself that unity. Some look upon this type, idea, or creative thought, as the soul. But such a view either annihilates soul by proclaiming 
indirectly materialism, or it annihilates it by absorbing it into the Deity, and proclaims Pantheism. The steam-engine is the realization of the thought of Watt, but one would hardly deem it satisfactory to call the thought of that philosopher the soul of the steam engine. And when we remember that all men are formed after a certain type, which is, moreover, common to all vertebrated animals, it is not easy to conceive any idea of type which may conform to the idea which we entertain of soul.

But the weightiest reason which operates in preventing man from recognizing the importance of the body, is the difficulty he experiences in conceiving its immortality. Job must surely have foreseen this when he prefaced his declaration upon that subject with the words-" Oh, that my words were now written! Oh, that they were printed in a book. That they were graven with an iron pen, and with lead in the rock for ever !" And what words were these so important to be remembered? "For I know that my Redeemer liveth, and that he shall stand at the latter day upon the earth; and though after my skin worms destroy this body, yet in my flesh shall I see God." St. Paul also seems to have foreseen the objections that might be made to the resurrection of the body, and to have recognized the necessity of such resurrection. "Thou fool! that which thou sowest is not quickened except it die. All flesh is not the same flesh. There are celestial bodies, and bodies terrestrial. It is sown in corruption, it is raised in incorruption; it is sown in weakness, it is raised in power. It is sown a natural body, it is raised a spiritual body. We shall not all sleep, but we shall all be charged." Well then might we add, " 0 death where is thy sting? 0 grave where is thy victory?" It is very certain that he who believes in a resurrection of the body, and it is impossible to believe that the Christian can doubt it, cannot, on the ground of a supposed materialism, object to any doctrine which maintains the essentiality of the body to individual existence. And there is no reason why he should wish to do so. Is not the construction of so delicate, yet so perfect and wonderful an organism, with such, to us, miraculous powers of transforming force, and developing the highest force in nature, as clear and convincing evidence of a Creator's skill, as any opinion which the ingenuity of man may form about mind? The potentiality which is inherent in the particular cerebral organization, is an expression of the power which mind exercises on the material supplied to 
it. Perhaps it is not so flattering a view to man's selfcomplacenoy, as that which attributes so special a character to mind, but it will be of some use, if it suggest to us the desirability of ceasing to limit the power of God by our conceptions and fancies. The universe, in all its departments, demonstrates the truth of Leibnitz's axiom, that "the present is pregnant with the future." And "the very analogy of a mundane birth suggests a still higher birth, viz, the entrance of the pre-existent and immortal ideal, as trained and developed by human life into new relations; its connexion with a superior organization; and its advancement to a higher and purer individuality. In this vier death is but a crisis in our being, the dissolution of the earthly tabernacle; not that we may be unclothed, but clothed upon, which is from above."*

The doctrine of the correlation of mental and physical force is, at any rate, not amenable to the objection that is brought with some force against the opinion commonly entertained of the soul, viz. "how can that which came into being yesterday be immortal ?" If it be said that the force of the objection lies in the imperfection of man, that his idea of soul, so far as he has any, is the representation to him of something existent from God, which he cannot completely comprehend, we may grant that it is so-the fact of actual existence incomprehensible by us, remains the same-and it becomes a question of the best mode of representation of it. Surely the doctrine of correlation as a representation thereof, is, at least, at the present time, most in accordance with man's knowledge, and most in accordance with the analogy of nature.

If there be any weight in the considerations which have been adduced, it is obvious that the supposed necessity of "a different order of things," in order to explain the moral nature, has no real existence. Unfortunate, indeed, would it be if such a necessity existed, for all observation showeth that moral character is as closely dependent on the character and condition of physical structure, as any other phenomenon physical or mental in man.

In conclusion, it may be well to cast a glance at the universe in its gradual evolution, from the formation of the first geological stratum, to the appearance and the last development of man-to note the thousands of years' existence of the earth before the creation of organic beings, the thousands of years more of existence, during which there

" Morell's "Eloments of Psychology," p. 83. 
was nothing but barren vegetation, and animals of low organization; the succession of eras up to man's appearance, and the thousands of years which man has required to arrive at his present condition. Is not such a history the disclosure of a succession of gigantic effects-effect following effect-at the proper time and season? the evidence of one mighty cause in operation? And does it not in truth appear monstrous to introduce into the series a new cause, not a new effect, related to, and gradually evolved, as it were, from previous effects, but a new cause unrelated and without cause. Harmonious development suddenly put a stop to, for the introduction of a miracle from the clouds! For how is it possible that this new introduction should act on things to which it has no relation; in fact, for this is the actual question, how should it be related to that to which it has no relation whatever. It might have been predicted that no possible conception could ever be formed of the action of mind on matter, if the "pro-established harmony" of Leibnitz and other such theories had not remained gigantic evidence to prove it. What does the history of the created universe tend to, if not to show that mind has been the gradual resultant of ages on ages of previous operations?'

All forces are then but modes of manifestation of one force-the Will of God-manifest in highest form, and with least obscuration in the temple of man's body. "Remark, as illustrative of several things, and more to the purpose here, that man does in strict speech always remain the clearest symbol of the Divinity to man. Friend Novalis, the devoutest heart I knew, and of purest depth, has not scrupled to call man, what the Divine Man is called in Scripture, a 'Revelation in the Flesh.' 'There is but one temple in the world,' says he, 'and that is the budy of man. Bending before men is a reverence done to this revelation in the flesh. We touch heaven when we lay our hand on a human body.' In which notable words, a reader that meditates them, may find such meaning and scientific accuracy as will surprise him."

\footnotetext{
"Carlyle's Miscellanies, vol. iii. “Goethe's Works."
} 


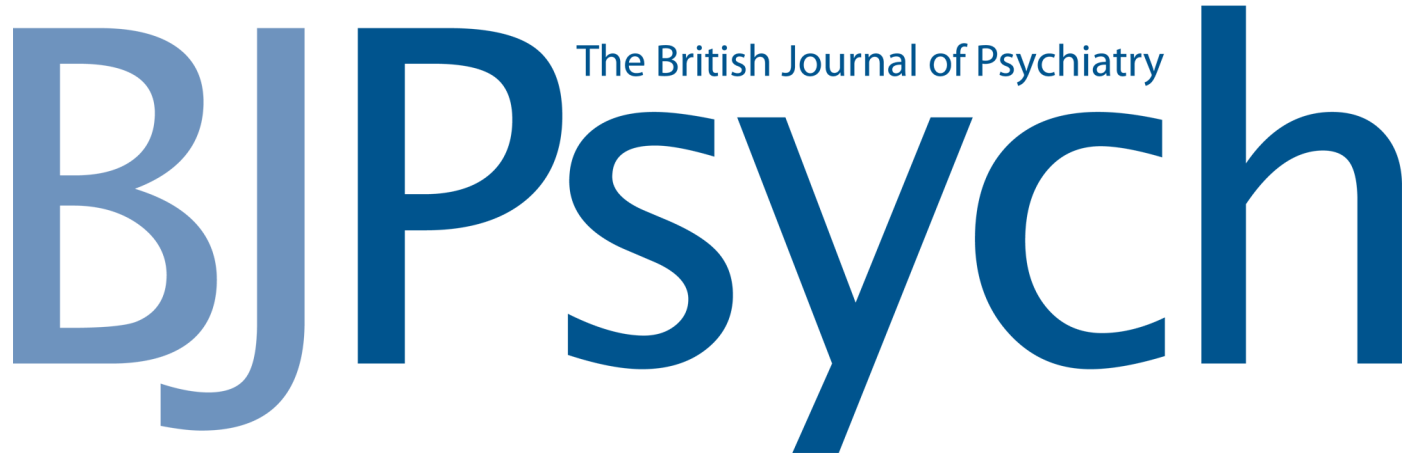

\section{The Correlation of Mental and Physical Force; or, Man a Part of} Nature

Henry Maudsley

BJP 1859, 6:50-78.

Access the most recent version at DOI: 10.1192/bjp.6.31.50

References This article cites 0 articles, 0 of which you can access for free at: http://bjp.rcpsych.org/content/6/31/50.citation\#BIBL

Reprints/ To obtain reprints or permission to reproduce material from this paper, please write permissions to permissions@rcpsych.ac.uk

You can respond /letters/submit/bjprcpsych;6/31/50

to this article at

Downloaded http://bjp.rcpsych.org/ on August 1, 2017

from Published by The Royal College of Psychiatrists

To subscribe to The British Journal of Psychiatry go to:

http://bjp.rcpsych.org/site/subscriptions/ 